\title{
MANTAN ORDO KAPUSIN PROVINSI MEDAN DARI TAHUN 2000 HINGGA 2012: KAUSA PENGUNDURAN DIRI
}

\author{
Gonti Simanullang*
}

\begin{abstract}
It is an undeniable fact that the number of young Capuchin candidates who have not been ordained priests from 2000 to 2012 resign, at their own choice and decision, from the Capuchin Order of Medan Province. This fact raises the question "Why did they withdraw from the Capuchin Order of the Province of Medan?" To answer this question we used exploratory research and methods of exit interview and exit questionary. It was found that there is a causal relationship between the increasingly firm belief in the inability to live celibate and the reason for withdrawing from the Capuchin Order of the Province of Medan. This finding is useful for finding ways that can help the Capuchin Order of the Province of Medan be able to monitor early gifts of celibacy or family life in candidates, such as when candidates are still in postulancy or novitiate.
\end{abstract}

Kata-kata kunci: mengundurkan diri, selibat, konflik, hidup doa, karunia, kharisma, Ordo Kapusin, Provinsi Medan.

* Gonti Simanullang, Doctor of Ministry Studies; lulusan Melbourne College Of Divinity, Auastralia; Dosen Teologi Pastoral pada Fakultas Filsafat Unika St. Thomas, Sumatera Utara. 


\section{Latar Belakang}

Ordo Kapusin ${ }^{1}$ Provinsi Medan (OKPM) menyelenggarakan Kapitel Biasa ${ }^{2}$ sekali setiap tiga tahun pada bulan Februari. Salah satu materi pembahasan dalam Kapitel Biasa itu adalah mendengar dan membahas Laporan Triennium (Latri) Minister Provinsial dan Dewan Penasihatnya (MPDP). Salah satu muatan Latri itu adalah data jumlah anggota OKPM yang meliputi postulan ${ }^{3}$, novis, ${ }^{4}$ pengkaul sementara, dan pengkaul kekal (laikus dan klerikus). Dalam dua Latri terakhir (20062009 dan 2009-2012) terdapat pertambahan jumlah anggota yang meninggalkan OKMP.

Untuk mengeksplorasi kenyataan ini, satu di antara keputusankeputusan Kapitel Biasa VII OKPM yang berlangsung 14-17 Februari 2012 di Nagahuta, Pematangsiantar, adalah "Kapitel menugaskan MPDP mengangkat tim untuk membuat penelitian mengapa banyak

1 Kapusin adalah sebutan akrab untuk Ordo Fratrum Minorum Capucinorum, yang biasa disingkat dengan OFMCap. Ordo ini adalah ordo termuda dalam Ordo Fransiskan. Pada tahun 1525, Pater Mateus dari Bascio (1495-1552), seorang observan di Montefalcone, Italia, berniat menegakkan kembali kesederhanaan asli Santo Fransiskus dari Assisi. Untuk tujuan itu, ia mendirikan Ordo Kapusin. [Lihat Adolf Heuken, Ensiklopedi Gereja, jilid IV (Jakarta: Cipta Loka Caraka, 2004), hlm. 30.]

2 Kapitel Biasa adalah kapitel yang dilaksanakan sekali dalam tiga tahun dan diundang oleh Minister Propinsial setelah mendapat persetujuan Minister Jenderal dan dewannya. Kapitel biasa bertugas dan berwenang memilih minister Provinsial dan Dewan Penasehatnya sesuai dengan ketentuan Kitab Hukum Kanonik dan Anggaran Dasar dan Konstitusi. Selain itu Kapitel juga mengadakan evaluasi atas masa bakti Minister Provinsial yang lalu dan menetapkan kebijakan untuk masa bakti yang berikut [Lih. Statuta Ordo Kapusin Provinsi Medan (tanpa penerbit, 1998), hlm. 30.]

${ }^{3}$ Postulan adalah sebutan bagi orang yang menjalani postulat. Postulat adalah tempat/rumah dan masa pembinaan tahap awal bagi calon-calon biarawan dari ordo atau kongregasi tertentu. Bagi Ordo Kapusin, postulat adalah tempat dan masa pembinaan calon-calon baru untuk mengenal cara hidup Kapusin [bdk. Norben Syukur, "OFS Mengejar Kesempurnaan Injili", dalam Hidup, 05/68, (02 Februari 2014), hlm. 9.]

4 Novis adalah calon angota suatu lembaga hidup religius (pria maupun wanita), yang sedang menjalani masa percobaan sebelum mengucapkan kaul religius awal, yakni hidup dalam ketaatan, kemiskinan, dan kemurnian (selibat). Dari kata novis muncul kata novisiat yang berarti baik rumah di mana novis dididik maupun masa pendidikan yang umumnya berlangsung sekurang-kurangnya setahun penuh. [Lihat Adolf Heuken, Ensiklopedi Gereja, jilid VI (Jakarta: Cipta Loka Caraka, 2004), hlm. 41.] 
saudara muda keluar." Yang dimaksud dengan "saudara muda" adalah calon-calon Kapusin yang menjalani pendidikan kekapusinan dari masa postulat hingga sebelum kaul kekal yang berlangsung sekitar 8 tahun.

Minister Provinsial OKPM, Emmanuel Sembiring, dalam Surat Tugas Nomor 0308/PM-034/PPM/VII/2012 mengangkat tiga saudara sebagai tim untuk meneliti faktor-faktor yang menyebabkan calon-calon muda meninggalkan OKPM. Tim peneliti itu adalah Richardus Sinaga, Herman Yosef Nainggolan, dan Gonti Simanullang. Di samping tugas ini, kepada tim diberikan juga wewenang untuk melengkapi keanggotaan baik dari kalangan Kapusin maupun dari luar kalangan Kapusin (kaum religius dan/atau awam lainnya).

Tim peneliti ini menjadi dua aliran: Richardus Sinaga dan Herman Yosef Nainggolan menjadikan sebagai responden semua calon yang keluar (yang menarik diri oleh keinginan calon sendiri dan calon yang diminta untuk menarik diri) dari OKPM. Sebaliknya, Gonti Simanullang memilih responden hanya calon yang mengundurkan diri atas pilihan dan keputusan calon sendiri. Hal ini diuraikan lebih rinci pada Pembatasan Masalah berikut.

\section{Pembatasan Masalah}

Kapitel 2012 OKPM memutuskan, antara lain, "Menugaskan MPDP mengangkat tim untuk membuat penelitian mengapa banyak saudara muda keluar." Muatan kata-kata vet ini adalah:

1) Kata 'banyak saudara muda' mencakup semua mantan saudara kapusin yang meninggalkan OKPM pada saat mereka tergolong kepada salah satu jenjang pendidikan berikut: novisiat, prakaul kekal, kaul kekal, diakonat. Saudara-saudara yang sudah menerima tahbisan imamat yang meninggalkan OKPM tidak termasuk dalam penelitian ini.

2) Kata 'keluar' memiliki dua implikasi: 1) mengambil keputusan untuk menarik diri dari OKPM atau 2) dianjurkan menarik diri atau dikeluarkan dari OKPM. Apabila seseorang dianjurkan menarik diri atau dikeluarkan dari OKPM, maka alasan kejadian itu terletak pada pihak OKPM. Sebaliknya, apabila seseorang mengambil keputusan untuk meninggalkan OKPM, maka alasan kejadian itu terletak pada orang bersangkutan. Apabila OKPM ingin mengetahui kausa mengapa seseorang dianjurkan meninggalkan OKPM, maka sumber informasi mengenai hal itu antara lain adalah testimonium dan persaudaraanpersaudaraan di mana saudara bersangkutan dibina, khususnya persaudaraan terakhir di mana saudara bersangkutan hidup dan 
berkarya dan akhirnya dikeluarkan. Sedangkan apabila OKPM ingin mengetahui kausa mengapa seseorang mengambil keputusan untuk meninggalkan OKPM, maka sumber utama dan pertama mengenai hal itu adalah saudara bersangkutan. Maka, setiap anggota yang keluar dari OKMP dapat digolongkan kepada salah satu di antara dua kondisi berikut: menarik diri atau dianjurkan untuk menarik diri.

3) Penelitian ini hanya melibatkan saudara-saudara muda: novis, saudara kaul sementara, dan saudara kaul kekal yang meninggalkan OKPM dari tahun 2000-2012.

4) Meninggalkan OKPM berarti saudara bersangkutan, berdasarkan kehendak bebasnya, memilih dan memutuskan untuk menarik diri dari OKPM. Saudara-saudara Kapusin yang imam yang meninggalkan OKPM dan saudara-saudara muda lainnya yang dianjurkan meninggalkan OKPM tidak termasuk dalam penelitian ini.

Maka pertanyaan penelitian adalah: Faktor-fakfor kausal apakah yang menyebabkan saudara-saudara muda dari tahun 2000 hingga 2012 mengundurkan diri berdasarkan pilihan dan keputusan pribadi dari OKPM?

\section{Tujuan Penelitian}

Tujuan penelitian ini adalah untuk menemukan dan menganilisis faktor-faktor yang menyebabkan saudara-saudara muda dari tahun 2000-2012 atas keputusan pribadi meninggalkan OKPM. Dengan menemukan faktor-faktor kausal yang menjelaskan mengapa saudarasaudara muda mengundurkan diri dari OKPM, maka OKPM akan tertolong untuk mengambil langkah-langkah yang lebih tepat dan jitu dalam mencegah kenyataan itu. Secara tidak langsung, produk penelitian ini berguna juga bagi ordo, tarekat atau kongregasi religius pria atau wanita lainnya di luar OKPM.

\section{Metode Penelitian}

Penelitian ini adalah penelitian yang menjelaskan (explanatory research $)^{5}$ faktor-faktor yang menyebabkan saudara-saudara muda dari tahun 2000-2012 mengundurkan diri dari OKPM. Pertanyaan yang mau dijawab adalah 'mengapa'. Untuk memperoleh jawaban atas pertanyaan

${ }^{5}$ Penelitian yang menjelaskan (explanatory research) disebut juga causal research (penelitian kausal). Pertanyaan yang hendak dijawab oleh penelitian yang menjelaskan adalah pertanyaan mengapa. [Lih. Brains, C., Willnat, L, Manheim, J., Rich, R., Empirical Political Analysis 8th edition (Boston, MA: Longman), hlm. 76. 
ini, dibutuhkan informasi dari responden yang mengundurkan diri dari OKPM. Untuk memperoleh informasi itu, digunakan exit questionnaire ${ }^{6}$ dan exit interview ${ }^{7}$. Informasi yang hendak diperoleh baik melalui kuesioner maupun wawancara adalah sama, yakni mengapa responden mengambil keputusan untuk mengundurkan diri dari OKPM. Faktorfaktor kausal apa yang menyebabkan mereka mengambil keputusan itu?

Menurut rekaman Kuria OKPM, jumlah novis dalam kurun waktu 2000-2012 terdapat sebanyak 165 orang. Dalam kurun waktu yang sama, orang yang keluar tercatat sebanyak 93 orang. Di antara 93 yang keluar itu tidak jelas seberapa banyak yang keluar meninggalkan OKPM berdasarkan keputusan sendiri. Namun demikian, peneliti berhasil mengidentifikasi 15 orang yang mengundurkan diri dari OKPM berdasarkan keputusan sendiri: 15 bersedia mengisi kuesioner dan 2 orang di antara mereka turut diwawancarai. Jumlah 15 ini bukan berarti hanya 15 orang saja yang mengundurkan diri dari OKPM berdasarkan keputusan sendiri dalam tahun 2000-2012. Beberapa kandidat responden yang beberapa kali dikontak via email dan kepada mereka kuesioner telah dikirim tidak bersedia menjadi responden.

\section{Temuan Penelitian}

Temuan penelitian ini terdiri atas data responden, motif mereka masuk OKPM, dan faktor-faktor kausal pengunduran diri.

\section{Data Responden}

Responden yang ada sebanyak 15 orang. Terdapat 10 responden yang mengundurkan diri sesudah dan saat TOP.

\footnotetext{
${ }^{6}$ Exit questionnaire adalah survei melalui kuesioner dengan responden yang mengundurkan diri atau memustuskan hubungan dari suatu organisasi. [Lih. Flavil R Yeakly, Why They Left: Listening to Those Who Have Left Churches of Christ, (Nashville, TN: Gospel Advocate Company, 2012), hlm. 17-18.]

7 Exit interview adalah survei melalui wawancara dengan seseorang yang mengundurkan diri atau memutuskan hubungan dari suatu organisasi. [Lih. Flavil R Yeakly, Why They Left: Listening to Those Who Have Left Churches of Christ, (Nashville, TN: Gospel Advocate Company, 2012), hlm. 21-22.]
} 
Logos, Jurnal Filsafat-Teologi, Vol. 14, No. 1, Januari 2017

\begin{tabular}{|c|c|c|c|c|c|c|c|}
\hline \multirow{2}{*}{$\begin{array}{c}\text { Tahun } \\
\text { Mengundur } \\
\text { kan diri }\end{array}$} & Jlh & \multicolumn{6}{|c|}{ Mengundurkan diri dari OKPM } \\
\cline { 3 - 8 } & $\begin{array}{c}\text { Jelang } \\
\text { Kaul } \\
\text { Kekal }\end{array}$ & $\begin{array}{c}\text { Post } \\
\text { Kaul } \\
\text { Kekal }\end{array}$ & $\begin{array}{c}\text { Post } \\
\text { TOP }\end{array}$ & $\begin{array}{c}\text { Saat } \\
\text { TOP }\end{array}$ & Tingkat & TPKK \\
\hline \hline $2000-2003$ & 5 & 2 & 0 & 1 & 2 & 0 & 0 \\
\hline $2003-2006$ & 1 & 0 & 0 & 0 & & 1 (III) & 0 \\
\hline $2006-2009$ & 4 & 0 & 0 & 0 & 2 & $1($ IV) & 1 \\
\hline $2009-2012$ & 5 & 1 & 1 & 1 & 2 & 0 & 0 \\
\hline
\end{tabular}

Catatan:

TOP : Kepanjagan TOP adalah Tahun Orientasi Pastoral. TOP berlangsung selama satu tahun sesudah calon telah menyelesaikan studi S1. Program TOP ini ditangani oleh satu tim yang disebut Tim TOP yang terdiri dari saudarasaudara Kapusin yang telah berkaul kekal dan/atau imam.

TPKK : Kepanjangan TPKK adalah Tahun Persiapan Kaul Kekal. TPKK berlangsung selama satu tahun yang ditangani oleh Tim TPKK. Tim TPKK ini terdiri dari saudara-saudara Kapusin yang telah berkaul kekal dan/atau imam.

\section{Motif Responden Masuk OKPM}

Faktor utama yang mendorong responden masuk OKPM adalah kehendak sendiri yakni 93\%. Kehendak sendiri ini didukung oleh ayah $77 \%$, oleh ibu 72\% dan oleh saudara-saudari kandung mereka 69\%.

\begin{tabular}{|l|c|c|c|c|c|c|}
\hline \multirow{2}{*}{ Motif masuk OKPM } & \multicolumn{7}{|c|}{ PENILAIAN } \\
\cline { 2 - 8 } & 1 STS & 2 TS & 3 N & 4 S & 5 SS & $\%$ \\
\hline \hline Kehendak sendiri & - & - & - & 5 & 10 & 93 \\
\hline Dukungan ayah & - & - & 4 & 8 & 3 & 77 \\
\hline Dukungan ibu & - & 2 & 4 & 7 & 2 & 72 \\
\hline $\begin{array}{l}\text { Dukungan saudara- } \\
\text { saudari kandung }\end{array}$ & 1 & 3 & 1 & 8 & 2 & 69 \\
\hline
\end{tabular}


Gonti Simanullang, Kausa Pengunduran Diri ...

STS : Sangat Tidak Setuju (nilai 1)

TS : Tidak Setuju (nilai 2)

$\mathrm{N} \quad$ : Netral (nilai 3)

S : Setuju (nilai 4)

SS : Sangat Setuju (nilai 5)

Salah satu faktor penunjang yang membuat mereka terdorong untuk masuk Kapusin adalah hidup doa dan kesederhanaan saudarasaudara Kapusin. Hal ini mereka ketahui antara lain dengan pernah tinggal di pastoran yang dihuni Kapusin.

\section{Faktor Kausal Pengunduran Diri}

Faktor-faktor kausal pengunduran diri responden dari OKPM adalah konflik di komunitas, semakin yakin akan hidup berkeluarga lebih cocok dari pada hidup selibat, dan keragu-raguan.

Konflik di komunitas

\begin{tabular}{|l|c|c|c|c|c|c|}
\hline \multirow{2}{*}{ Pernyataan } & \multicolumn{6}{c|}{ PENILAIAN } \\
\cline { 2 - 7 } & 1 STS & 2 TS & 3 N & 4 S & 5 SS & \% \\
\hline $\begin{array}{l}\text { Konflik dengan saudara senior } \\
\text { di komunitas }\end{array}$ & 3 & 2 & 0 & 5 & 5 & 69 \\
\hline $\begin{array}{l}\text { Konflik dengan bukan pembina } \\
\text { di komunitas }\end{array}$ & 7 & 4 & 4 & 0 & 0 & 36 \\
\hline $\begin{array}{l}\text { Kehidupan riil di komunitas } \\
\text { tidak seindah sebelum aku } \\
\text { masuk }\end{array}$ & 1 & 3 & 6 & 5 & 0 & 60 \\
\hline
\end{tabular}

Salah satu faktor yang menyebabkan responden mengundurkan diri dari OKPM adalah konflik dengan saudara-saudara senior (telah berkaul kekal dan/atau imam). Konflik ini dipicu oleh isi teguran saudara senior. Isi teguran itu berseberangan dengan persepsi responden. Terjadilah adu argumentasi yang akhirnya menimbulkan komunikasi macet. Akibat lanjut dari konflik ini adalah bahwa relasi dan komunikasi menjadi dingin dan macet dalam kehidupan bersama di komunitas. Di bawah ini disertakan pernyataan-pernyataan signifikan dari responden tentang konflik yang dialami dalam komunitas. 
- Ada anggota komunitas yang iman bersikap otoriter dan "tuhan kecil".

- Pernah saya mengalami kecelakaan dan saya dipersalahkan habis-habisan oleh pastor paroki. Saya merasa tidak diperlakukan sebagai saudara. Selain itu, tak seorang pun anggota komunitas memerhatikan saya yang dalam proses pemulihan kesehatan.

Semakin yakin akan hidup berkeluarga

\begin{tabular}{|l|c|c|c|c|c|c|}
\hline \multirow{2}{*}{ Pernyataan } & \multicolumn{7}{|c|}{ PENILAIAN } \\
\cline { 2 - 7 } & 1 STS & 2 TS & 3 N & 4 S & 5 SS & \% \\
\hline $\begin{array}{l}\text { Semakin yakin bahwa hidup } \\
\text { di luar OKPM lebih cocok } \\
\text { bagiku }\end{array}$ & 0 & 0 & 3 & 7 & 5 & 82 \\
\hline $\begin{array}{l}\text { Semakin yakin bahwa hidup } \\
\text { berkeluarga lebih cocok } \\
\text { daripada selibat }\end{array}$ & 0 & 0 & 3 & 6 & 6 & 84 \\
\hline
\end{tabular}

Sesudah menjalani hidup kekapusinan selama sekian tahun, responden makin meyakini bahwa hidup di luar OKPM lebih cocok baginya. Hal ini diteguhkan keyakinan bahwa hidup berkeluarga lebih cocok baginya dari pada selibat. Keyakinan akan hidup berkeluarga ini tidak didukung oleh faktor keturunan yang diharapkan oleh orang tua dari mereka. Pada umumnya cita-cita mereka untuk menjadi kapusin didukung oleh keluarga sebagaimana nyata dalam Tabel 5.2 di atas. Di bawah ini disajikan pernyataan signiffikan responden:

- Saya sangat kesepian tanpa lawan jenis dan tidak mau menjalin relasi khusus dengan siapapun lawan jenis karena bagiku itu bertentangan dengan kaul. Rasa sepi itu membuatku makin yakin bahwa hidup berkeluarga lebih cocok bagiku daripada selibat.

- Saya sadar akan keterbatasan diriku dalam menjalani kaul kemurnian. Karena itu, saya semakin yakin bahwa hidup berkeluarga lebih cocok bagiku daripada selibat.

Keyakinan akan hidup di luar OKPM dan berkeluarga lebih cocok bagi responden dari pada selibat didukung oleh pengalaman hidup sesudah mereka mengundurkan diri dari OKPM dan berkeluarga. 
Gonti Simanullang, Kausa Pengunduran Diri ...

\begin{tabular}{|l|c|c|c|c|c|c||}
\hline \multirow{2}{*}{ Pernyataan } & \multicolumn{6}{|c||}{ PENILAIAN } \\
\cline { 2 - 7 } & 1 STS & 2 TS & 3 N & 4 S & 5 SS & \% \\
\hline \hline $\begin{array}{l}\text { Sesudah sekian lama } \\
\text { meninggalkan OKPM, aku } \\
\text { mengalami bahwa keputusanku } \\
\text { mengundurkan diri dari OKPM } \\
\text { tepat }\end{array}$ & 0 & 0 & 5 & 5 & 5 & 93 \\
\hline
\end{tabular}

Situasi sebelum mengundurkan diri

\begin{tabular}{|l|c|c|c|c|}
\hline \multirow{2}{*}{$\begin{array}{c}\text { Situasi sebelum mengundurkan } \\
\text { diri }\end{array}$} & \multicolumn{4}{|c|}{ PENILAIAN } \\
\cline { 2 - 5 } & Ya & $\%$ & No & $\%$ \\
\hline $\begin{array}{l}\text { Ragu-ragu sekurang-kurangnya } 6 \\
\text { bulan }\end{array}$ & 12 & 80 & 3 & 20 \\
\hline $\begin{array}{l}\text { Berbicara kepada pembimbing } \\
\text { rohani tentang rencana } \\
\text { pengunduruan diri }\end{array}$ & 8 & 53 & 7 & 47 \\
\hline
\end{tabular}

Umumnya responden telah ragu-ragu sekurang-kurangnya 6 bulan, bahkan ada sejak responden menjalani novisiat, sebelum ia memutuskan untuk mengundurkan diri dari OKPM. Ketika responden mengemukakan keragu-raguannya kepada pembimbing rohani dan teman-teman seangkatan mereka, pembimbing rohani dan teman-teman itu sering menganjurkan agar responden bertahan dan mencoba lagi. Namun demikian anjuran itu tidak begitu berkhasiat, sebab di antara 15 responden terdapat 13 yang telah ragu-ragu sekurang-kurangnya 6 bulan pada akhirnya mengundurkan diri.

Di antara 15 responden, terdapat 7 responden yang tidak mengemukakan keragu-raguan mereka kepada pembimbing rohani. Itu berarti bahwa keragu-raguan itu, entah dikemukakan atau tidak kepada pembimbing rohani, tidak begitu berpengaruh kepada keputusan untuk mengundurkan diri di kemudian hari.

Terdapat 3 responden yang telah menulis Surat Permohonan Kaul Kekal, tetapi kemudian membatalkannya. Seorang di antaranya, sesudah menulis Surat Permohonan Kaul Kekal itu dan masih menyimpannya, tidak bisa tidur dan menderita sakit kepala selama seminggu. Sesudah membatalkan surat itu dan memberitahukan 
pembatalan kepada guardiannya bahwa ia tidak berkaul kekal, sakit kepalanya hilang dan ia bisa tidur kembali. Responden ini sudah raguragu akan panggilannya selama kurang lebih satu tahun. Keraguraguannya ini dipicu oleh pola hidup yang kurang baik dari seseorang senior di dalam komunitasnya. Seorang lagi, karena masih tetap raguragu, walau sudah sempat menulis Surat Permohonan, akhirnya membatalkannya.

\section{Hidup doa}

Hidup doa responden setelah sekian lama menjadi Kapusin tidak begitu berpengaruh pada keputusannya untuk menarik diri dari OKPM. Mereka tidak mengalami kesulitan dalam mengikuti hidup doa menurut aturan komunitas.

\begin{tabular}{|l|c|c|c|c|c|c|}
\hline \multirow{2}{*}{ Pernyataan } & \multicolumn{6}{|c|}{ PENILAIAN } \\
\cline { 2 - 7 } & 1 STS & 2 TS & 3 N & 4 S & 5 SS & \% \\
\hline $\begin{array}{l}\text { Hidup doa tidak berkembang } \\
\text { selama menjadi kapusin }\end{array}$ & 1 & 9 & 1 & 2 & 2 & 48 \\
\hline $\begin{array}{l}\text { Tidak bisa mengikuti hidup } \\
\text { doa menurut aturan } \\
\text { komunitas }\end{array}$ & 3 & 8 & 1 & 2 & 1 & 41 \\
\hline Sulit bermeditasi & 2 & 9 & 2 & 2 & 0 & 45 \\
\hline
\end{tabular}

Memang ada responden yang mengatakan bahwa kehidupan doanya kurang berkembang karena praktek hidup doa saudara-saudara sekomunitasnya sebagaimana diungkapkan dalam pernyataan signifikan di bawah ini.

- Idealismeku tinggi dengan spiritualitas kapusin. Maka, ketika para saudara jauh dari pola hidup miskin, jauh dari hidup doa yang kuat dan rutin, jauh dari disiplin hidup, kurang bersemangat melayani dengan tuntas dan radikal, saya menjadi sangat terganggu dan membayangkan para saudara inilah kelak yang akan menjadi saudaraku sepanjang masa.

- Saya menarik diri karena setelah sekian lama kucoba untuk menghayati spiritualitas kekapusinan, di mana saya berharap, semakin lama akan semakin saya hidupi, tetapi kenyataannya sebaliknya, semakin lama saya semakin jenuh dan bosan. Hidup rohani saya tidak berkembang, seolah-olah saya hanya mengikuti rutinitas belaka, tanpa ada nilai yang saya dapatkan. 
Gonti Simanullang, Kausa Pengunduran Diri ...

- Seingat saya hidup sebagai kapusin adalah vita mixta, yakni ada cita rasa hidup karya dan doa. Berdasarkan pengamatan saya, termasuk atas hidup saya sendiri saat masih dalam OKPM, hidup karya saya lebih dominan dari doa, sementara doa saya juga belum dapat menopang karya saya. Doa yang saya maksudkan adalah doa dan kesalehan pribadi dari pada doa ofisi dan ekaristi. Saya sering merasa gersang dan kering pada saat berkarya atau setelah berkarya. Namun saya sadar itu semua karena saya kurang berdoa. Bagaimana memaknai karya sebagai wujud doa dan doa sebagai penopang karya? Dalam praksis hidup saudara muda, hal ini masih menjadi perjuangan berat. Maka kehadiran formator yang dapat memberikan bimbingan dan tempaan hidup doa di masa-masa postulat, novisiat, dan skolastikat sangat signifikan pengaruhnya, karena pada masa TOP praktisnya para saudara muda seakan "tidak" dalam proses pembinaan.

Di atas disebutkan bahwa terdapat 4 faktor dalam kaitannya dengan keputusan responden mengundurkan diri dari OKPM. Faktor hidup doa, selain tiga pernyataan signifikan dari tiga responden, tidak begitu berpengaruh pada keputusan mereka untuk mengundurkan diri dari OKPM. Ketiga faktor lainnya mempengaruhi keputusan responden. Ketiga faktor inilah hendak dielaborasi lebih lanjut di bawah ini.

1) Semakin yakin akan hidup berkeluarga lebih cocok bagi responden.

Terdapat hubungan kausal antara keyakinan akan hidup berkeluarga dan keputusan mengundurkan diri dari OKPM. Menganut hidup kapusin berarti menganut hidup wadat. Maka ketika responden makin bertumbuh dalam keyakinan bahwa hidup berkeluarga lebih cocok baginya, maka pengalaman hidup selaku kapusin selama ini merupakan masa pemurnian panggilan hidup kapusin, sampai akhirnya responden sampai kepada keputusan untuk mengundurkan diri dari OKPM. Di sini terdapat hubungan kausal yang deterministik, yakni keyakinan akan hidup berkeluarga lebih cocok bagi responden dapat dipastikan akan mengakibatkan responden mengundurkan diri dari OKPM yang menganut hidup selibat. Maka, calon-calon lain, apabila telah sampai kepada keyakinan bahwa hidup berkelurga lebih cocok baginya, akan mengundurkan diri dari OKPM.

Pertanyaan refleksif adalah bagaimanakah OKPM sanggup lebih dini memantau karunia hidup selibat atau berkeluarga dalam diri calon, misalnya ketika calon itu masih menjalani masa postulat? 
2) Konflik dalam komunitas.

Apakah ada hubungan kausal antara konflik di komunitas dan keputusan untuk mengundurkan diri dari OKPM? Dengan hubungan kausal di sini berarti konflik itu mengakibatkan responden mengundurkan diri dari OKPM. Karena ternyata terdapat responden yang menarik diri walau tidak mengalami konflik dalam komunitas, maka hubungan kausal di sini lebih bersifat probabilistik bukan deterministik. Probabilistik di sini berarti kenyataan konflik itu dapat menguatkan responden untuk mengambil keputusan mengundurkan diri dari OKPM. Dengan demikian boleh dikatakan, bahwa tidak setiap orang yang mengalami konflik akan mengundurkan diri dari OKPM. Kematangan pribadi, kesanggupan calon mengolah konflik turut mempengaruhi keputusannya.

Pertanyaan adalah: a) bagaimana anggota-anggota OKPM membangun komunikasi yang lancar dan hangat dalam komunitas? b) bagaimana teguran dan kritik dikomunikasikan tanpa menimbulkan sakit hati? c) bagaimana anggota-anggota OKPM mengembalikan correctio fraterna (koreksi persaudaraan) yang tulus dan jujur yang diyakini bagian integral dalam membangun persaudaraan dalam OKPM? d) apakah anggota-anggota OKPM sesering mungkin menerima Sakramen Tobat?

3) Keragu-raguan.

Ada adagium yang berbunyi, "Lebih baik mundur dari pada ragu-ragu." Persentase responden yang mengundurkan diri yang dipengaruhi keragu-raguan cukup tinggi, yakni $80 \%$. Walaupun motif awal mereka untuk masuk Kapusin merupakan kehendak sendiri, tetapi dalam perjalanan panggilan mereka keragu-raguan bisa muncul, bahkan berlangsung lama. Konflik dan pola hidup di komunitas boleh mempengaruhi responden menjadi ragu-ragu, lebih-lebih bila konflik itu tidak diatasi.

Apakah ada hubungan kausal antara keragu-raguan dengan keputusan untuk mengundurkan diri? Bila ada hubungan kausal, apakah sifatnya deterministik atau probabilistik? Keragu-raguan di sini, seperti konflik dalam komunitas, bersifat probabilistik. Keragu-raguan bisa memperkuat keputusan responden untuk menarik diri. Tetapi tidak boleh dikatakan bahwa keragu-raguan mengakibatkan keputusan menarik diri. 
Gonti Simanullang, Kausa Pengunduran Diri ...

Pertanyaan refleksif adalah: a) apa yang bisa dibuat oleh OKPM untuk membantu saudara yang ragu-ragu akan panggilannya? b) bagaimanakah keragu-raguan dapat diubah menjadi kepastian?

\section{Dampak Kekapusinan}

Hidup kekapusinan yang telah dialami oleh responden memberi pengaruh positif dan signifikan bagi mereka dalam menghidupi hidup mereka yang sekarang sesudah mereka mengundurkan diri dari OKPM. Walaupun mereka pernah mengalami konflik, sakit hati, dan teladan yang kurang dari teman-teman sekomunitas, namun mereka mendukung anak mereka jika di antara anak-anak mereka ada berkeinginan masuk Kapusin.

\begin{tabular}{||l|c|c|c|c|c|c||}
\hline \multirow{2}{*}{ Pernyataan } & \multicolumn{6}{c||}{ PENILAIAN } \\
\cline { 2 - 7 } & 1 STS & 2 TS & 3 N & 4 S & 5 SS & \% \\
\hline $\begin{array}{l}\text { Hidup sebagai kapusin } \\
\text { memberi kekuatan dalam } \\
\text { menghidupi hidupku } \\
\text { sekarang }\end{array}$ & 0 & 0 & 0 & 9 & 6 & 89 \\
\hline $\begin{array}{l}\text { Mendukung anakku yang } \\
\text { berkeingingan masuk Kapusin }\end{array}$ & 0 & 0 & 0 & 5 & 10 & 93 \\
\hline
\end{tabular}

\section{Kesimpulan}

Pertanyaan penelitian ini adalah faktor-fakfor kausal apakah yang menyebabkan saudara-saudara muda dari tahun 2000-2012 mengundurkan diri berdasarkan keputusan pribadi dari OKPM? Tiga faktor utama dalam mempengaruhi responden mengambil keputusan untuk mengundurkan diri dari OKPM. Ketiga faktor itu adalah konflik dalam komunitas, keyakinan akan hidup berkeluarga, dan keragu-raguan. Konflik dalam komunitas dan keragu-raguan bersifat probabilistik, sementara keyakinan akan hidup berkeluarga bersifat deterministik, dalam hubungan dengan keputusan untuk mengundurkan diri.

Tawaran untuk mengelaborasi faktor-faktor di atas telah dicoba dengan mengajukan pertanyaan-pertanyaan. Pertanyaan-pertanyaan itu masih parsial, bukan konprehensif. Karena itu refleksi bersama sangat perlu untuk sampai pada langkah-langkah yang tepat guna. 
Walaupun jumlah saudara Kapusin yang mengundurkan diri dari OKPM bertambah, namun pengalaman hidup selaku kapusin memberi dampak signifikan dalam menghidupi kehidupan mereka yang sekarang. Itu berarti bahwa pengalaman hidup sebagai Kapusin selama sekian tahun tidaklah percuma, bahkan mereka mendukung anak-anak mereka untuk masuk Kapusin.

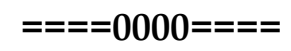

\section{DAFTAR PUSTAKA}

Brains, C., Willnat, L,, Manheim, J., Rich, R. Empirical Political Analysis 8th edition. Boston, MA: Longman, 2011.

Heuken, Adolf. Ensiklopedi Gereja, jilid IV. Jakarta: Cipta Loka Caraka, 2004.

-. Ensiklopedia Gereja, jilid VI. Jakarta: Cipta Loka Caraka, 2004.

Statuta Ordo Kapusin Propinsi Medan. 1998.

Syukur, Norben. “OFS Mengejar Kesempurnaan Injili." Hidup, Februari 2, 2014: 9 .

Yeakley, Flavil R. Why They Left: Listening to Those Who Have Left Churches of Christ. Nashville, TN: Gospel Advocate Company, 2012. 